\title{
Access to the Infrastructure of Settlement for Sustainable Development Goals in Rural District Semarang, Central Java, Indonesia
}

\author{
Puji Hardati \\ Department of Geography \\ State University of Semarang \\ Semarang, Indonesia \\ Corresponding email: puji.hardati@mail.unnes.ac.id
}

\begin{abstract}
This study aims to analyze access to settlement infrastructure. Settlements infrastructure is one aspect that has not been achieved on the Millennium Development Goals. The goal of sustainable development is a continuation of the millennium development goals, which began in 2016 and ended 15 years later. This research was conducted in the District of Semarang, using quantitative methods. The variables used were household, housing conditions, and settlement infrastructure. The data used is secondary data, which comes from the Central Bureau of Statistics. Data analysis using descriptive method and the percentage of the index, are presented in tables and figures. The results showed that not all rural households can access to the infrastructure of settlement. Most rural households in access infrastructure positions moderate classification, sustainable development goals is for all. There are about 6 percent of rural households live in houses do not have sanitation. Approximately 4.56 percent of households that use the main source of drinking water from unprotected. Most households use drinking water from unprotected springs, located in an area close to the natural water sources or springs.
\end{abstract}

Keywords-Infrastructure, settlement, rural, sustain-able development goals.

\section{INTRODUCTION}

Development is basically aimed at the welfare of the population. Development lasts a lifetime, so development is a sustainable process. Sustainable implies, social, economic, and environmental. The concept of sustainable development is not a new concept, because it has been discussed by some experts, such as Malthus (1798) and Meadow (1972) in Baiquni and Susilowardani (2003). Sustainable development has been agreed as development that meets the needs of the present and not sacrifice the rights of meeting the needs of future generations. Understanding sustainability is very complex, multi-dimensional, and multi interpretation (Fauzi and Alex, 2014).

The success of development in a country is not the same and very varied. The United Nations has agreed, to determine the success of the development, formulate development indicators into development goals. The period 2000-2015, the indicators are formulated into millennium development goals (MDGs) by eight pillars and sixty-nine indicators. The next period, in 2015-2030, the development goals formulated in the sustainable development goals (SDGs), contains seventeen goals, and one hundred and sixty-nine development targets (Sam, 2015).

Sustainable development goals agreed on and apply to all, all nations without exception, both in developed countries and in developing countries. Sustainable development targets wider compared with the millennium development goals. Sustainable development goals are then formulated by each country in its development goals each. Indonesia, as countries in the world the other also makes the formulation of sustainable development goals into the formulation of national development goals.

Development in Indonesia has started since independence until now, and will continue until the future. The results of today's development are inseparable from the result of past development, and for generation to the future. Results of development can be studied from various aspects, such as achievements and various global awards. The success of the development, among others, Indonesia into the G-20 forum, which groups 20 countries that have 85 percent of gross domestic income of the world, Indonesia's role in setting global policy becomes very important. The result of the development has not reached 100 percent as mandated in the national development planning documents. This situation can be seen from various sectors and coverage area. As there is still a dichotomy between urban and rural, agricultural and industrial sectors. The population residing in villages around 60.2 percent (Central Bureau of Statistics, 2011). Number of poor in rural areas ranges from 20.2 percent (Central Bureau of Statistics, 2003).

Development indicators that have been formulated on the millennium development goals, and ended in 2015, there are still some targets have not been achieved. The indicator is the decline in maternal mortality rate, infant mortality rate, decreased rates of AIDS / HIV, coverage of drinking water and sanitation 
(Hoelman, 2015). The four objectives have not been achieved was formulated back into sustainable development goals. Sustainable development goals began in 2016 and will end in 2030.

Goals 6, formulated on the SDGs, including indicators of drinking water and sanitation coverage, which ensures the availability and management of sustainable clean water and sanitation for all. The purpose 6 of the SDGs, most of the indicators contained in the settlement infrastructure. Infrastructure is a facility required by the population, to public functions (Kondoatie, 2005). Residential infrastructure is a set of facilities required for the functioning of the public, and should be available in your neighborhood or residential livelihood support. Infrastructure grouped into three types, namely infra-structure that supports accessibility, infrastructure supporting food production, and infrastructure supporting basic needs. Infrastructure settlement included into such groups infrastructure to support the basic needs of the population, consisting of drinking water supply and sanitation (Asnudin, 2009).

Residents need a house for shelter. The houses whose existence is grouped called the housing. Housing is a group home that serves as a housing area or dwelling incorporating environmental infrastructure i.e. the basic physical completeness environment. The settlements are part of the environment outside the protected forest area, either in the form of urban and rural areas. Settlement serves as a housing area or dwelling and place of residence or place of activities that support life and livelihood.

Settlement infrastructure is the basic accessory physical environment that allows neighborhoods to function properly. Residential infrastructure is one component of the physical assets. Livelihoods assets consist of five components of assets, that is a physical asset, natural asset, human asset, social asset, and financial asset (Hardati, 2014). Settlement Infrastructure one from physical asset should be owned by every household (Rijanta, 2008). The sustainable household should have access to the assets and activities.

The availability of drinking water and sanitation is monitored through the indicator of the proportion of households that have access to drinking water, the proportion of households have access to sanitation. Residential infrastructure problems are still reaping the majority located in rural areas. Not to all the residents in the household can access residential infrastructure. This article aims to examine the infrastructure for housing in Semarang regency, Central Java province.

Settlement infrastructure is one of the most important facilities and physical assets should be owned by every resident in the household. Infra-structure is a physical system that sustains the social system, economy and improves welfare (Kondoatie, 2005). Several studies on the infra-structure of settlements have been done in many countries and some experts. Conditions residential infra-structure in Nigeria cannot be considered satisfactory (Adedayo and Sulyman, 2015). Similarly, a study in the United States by Aschauer (1989) and Munncell (1990) in study Dikun (2003) showed that the rate of return on infrastructure investment to economic growth contributed $60 \%$.

\section{METHOD}

Research conducted at the Semarang District, with consideration of most of the region was still a village, that there is 88.51 percent. The location adjacent to the City of Semarang, the Capital City of Central Java Province

The research variables are residential infrastructure consists of residential conditions, sanitation, facility latrines, where the final disposal of feces, and the main source of drinking water, electricity and telephone networks. The data used is secondary data, derived from the Central Bureau of Statistics, documents Regional Medium-Term Development Plan, Medium Term Development Report Regional Development.

Data was analyzed using descriptive percentage, index, scoring and maps. The map describes the spatial distribution. Map function to make it easier to read and analyze geographical (spatial, environment and complex region) are associated with a location that has quality infrastructure is categorized into three, namely high, medium and low. The results of the analysis are presented in tables and figures.

\section{FINDING AND DISCUSSION}

\section{A. Regional Overview Research}

Semarang regency is one area in Central Java Province. It's location in the South Form City of Semarang. Bordered by some regions, the north bordered are Regency of Demak and Semarang, the South is bordered by the town of Magelang, West side of Kendal regency, and the East with Grobogan. Administratively, has 19 sub-districts.

Semarang District is a central area of industrial development, there are 190 pieces of big industry, thousands of small industry and households. Large industries are able to absorb about 72 thousand workers. Industrial workers from the local area and outside the region, so many migrants.

Residents who came to Semarang regency increasing. By 2015 the population of 955481 souls, five years earlier, namely on 2010, the population of 933764 inhabitants. The average population growth every year for years 2010-2015 amounted to 0.46 percent. In 2015, there is 1.03 percent in number of migrants, and in 2010, 0.99 percent of migrants. Number of growing population led to the higher population density. Over the past 5 years, the density increased 23 points, in 2010 the population density figure of 983 inhabitants /square kilometers 
into 1006 inhabitants /square kilometers in 2015 (Central Bureau of Statistics, 2015).

Despite this, in 2015, the number of people working in the agricultural sector is only 19.19 percent of the total working population. In fact, in 2005, there was 38.89 percent. Thus, during the ten-year period there has been a shift in the number of people working in agriculture. It has also been described (Hardati and Rijanta, 2013) that there was a shift in Semarang District labor in the agricultural sector leading to the non-agricultural sector. Employment non-agricultural sector of the dominant chosen by the majority of the population is the manufacturing and services.

\section{B. Access to the Settlement Infrastructure}

Access to the infrastructure comprising settlement access to houses, electricity, telephone, sanitation and drinking water sources.

\section{- Access to House Live}

In Semarang regency, in 2015, most of the population lived in permanent homes, which reached 53.33 percent. But many residents who live at home are not permanent, i.e. 24.38 percent. Most of the population residing in the home are not permanent residents are included in the category of the poor, people who are located in villages with low accessibility.

\section{TABLE 1. CHARACTERISTICS HOUSE LIVE AT THE SEMARANG} DISTRICT

\begin{tabular}{|l|l|}
\hline Characteristics & Number (percent) \\
\hline Housing conditions & 53,33 \\
\hline Permanent & 20,38 \\
\hline Semi-permanent & 24,38 \\
\hline Not-permanent & 11,41 \\
\hline Others & 37,16 \\
\hline The condition of the floor & 12,38 \\
\hline Ceramics & 28,30 \\
\hline Tiles & 1,19 \\
\hline Cement & 24,42 \\
\hline Wood & \\
\hline Soil & 99,99 \\
\hline Power source electricity & 0,01 \\
\hline PLN & Sources: Central Bureau Statistics and Analysis \\
\hline Non-PLN
\end{tabular}

Condition of the house to be an asset, because the house is one of the livelihood assets. Sustainable development goals, recommends that all households live in permanent housing. The home is the physical assets supporting livelihoods in rural areas (Elli, 2000). Every household has a permanent home will feel comfortable and safe.

Type of residential house floor, made of various types: ceramic tiling, wood, and soil. In Semarang District, threequarters (75.58 per cent) of households already have a permanent home, and there are nearly a quarter (24.42 percent) of the house, the floor was made from the ground.

\section{- Access to Sanitation}

Sanitation, containing the toilet and the main source of drinking water used by households. The ownership status of household latrines consists of their own latrines, latrines shared, communal latrines, and no latrine. Household latrine ownership status is not the same and the amount varies, as presented in Table 2.

\section{TABLE 2. STATUS OF HOUSEHOLD LATRINES IN THE DISTRICTS OF SEMARANG}

\begin{tabular}{|l|l|}
\hline Latrine ownership status & Number (percent) \\
\hline Own latrines & 74,20 \\
\hline Latrines together & 10,37 \\
\hline Public latrines & 1,93 \\
\hline No latrine & 13,50 \\
\hline \multicolumn{2}{|c|}{ Sources: Central Bureau Statistics and Analysis }
\end{tabular}

Households mostly own their own latrines, the number is 74.20 percent. While households do not have latrine, the number of 13.50 percent. Households with communal latrines or jointly and public toilet in number 12.30 percent. Households that do not have latrines, mostly households residing in the house is not permanently located less acces-sible regions is low.

Household latrine ownership conditions contained in the study area is similar to that found in some other areas. As expressed by Adedayo and Sulyman (2015), that the service quantity and quality of water supply has not been satisfactory.

\section{- Access to Primary Drinking Water Sources}

The main source of drinking water used by household's assortment, i.e. bottled water, plumbing, retail plumbing, pumps, protected wells, protected springs, wells and springs unprotected. At this time, there are households that uses drinking water from bottled water (4.39\%). Households who use drinking water from bottled water mostly households who work in the factory. This is supported by a number of traders bottled water is more and more from year to year (Hardati, 2008)

TABLE 3. SOURCES OF DRINKING WATER MAIN USE HOUSEHOLDS IN THE DISTRICT OF SEMARANG

\begin{tabular}{|l|c|}
\hline Drinking Water Sources & Number (percent) \\
\hline Bottled water & 4,39 \\
\hline
\end{tabular}




\begin{tabular}{|l|c|}
\hline Plumbing & 12,50 \\
\hline Plumbing retail & 2,82 \\
\hline Pump & 2,82 \\
\hline Protected wells & 40,61 \\
\hline Protected springs & 25,33 \\
\hline Unprotected wells & 7,12 \\
\hline Unprotected springs & 4,41 \\
\hline
\end{tabular}

Access to the residential infrastructure categorized into three, namely low, medium, and high. In general, household access to infrastructure for housing included in the medium category. Subdistricts that are included in the high category only 5.26 percent of the 19 regions overall. The area is included in the category of medium amount 26.32 percent, and the region including the lower category there are 69.42 percent.

\section{TABLE 4. DISTRIBUTION CATEGORY VALUE INDEX SETTLEMENT INFRASTRUCTURE}

\begin{tabular}{|c|c|}
\hline Category & Number (percent) \\
\hline Hight & 5,26 \\
\hline Medium & 26,32 \\
\hline Low & 69,42 \\
\hline
\end{tabular}

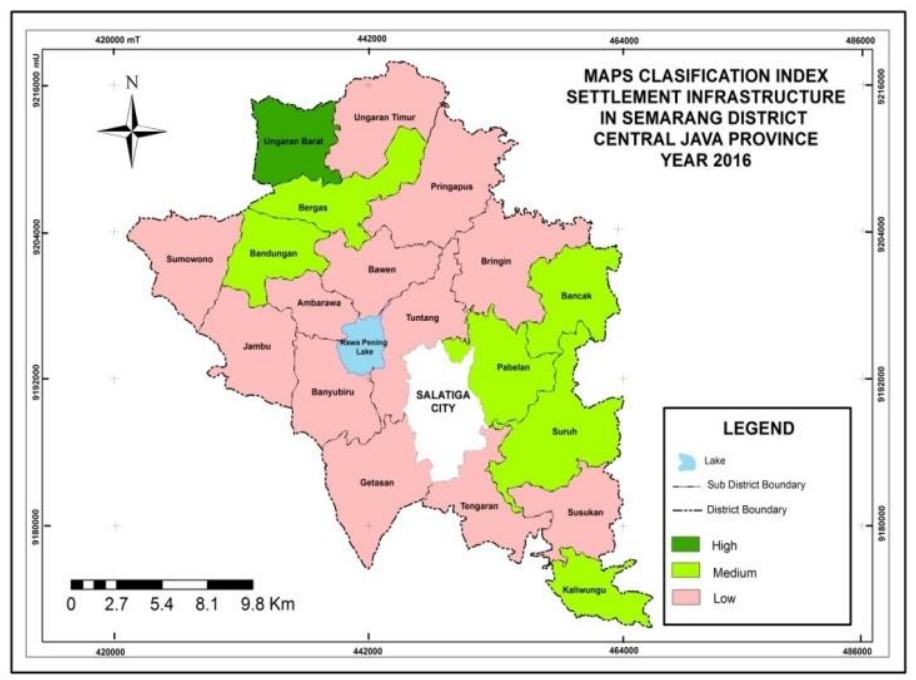

Fig. 1. Distribution Map Classification Index of Infrastructure for housing in Semarang District

Access to the spatial distribution of residential infrastructure is very varied, because each region has characteristics that are not the same. Location regions with high-class residential infrastructure access, have high accessibility, and became the center of people's activities. While the location of the region with access to infrastructure for housing the low category, spread in some areas and lower accessibility (Figure 1 and Table 4).

Households that use drinking water from the tap is still very small (12.50 percent), the dominant source of drinking water comes from protected wells (40.61 percent), and there are still households who use drinking water from unprotected wells and drinking water sources from unprotected springs. In fact, the source of drinking water is not recommended for use.

Low residential infrastructure spread across most of the rural areas. Characteristics of the majority of households residing in the home are not permanent, and the floor of the house made from soil. In addition, households in rural areas still use shared latrines and public toilets, and found to households that do not have latrines. The situation is exacerbated by the source of drinking water key used in rural households. Still, there are sources of drinking water comes from unprotected springs and wells are not protected, and there is a household to meet the needs of drinking water comes from bottled water.

Efforts to increase the number of households to access residential infrastructure has been carried out various development. Form of development that has been done to improve the infrastructure for housing among others through PAMSIMAS, rural infrastructure development program (Asnudin, 2009). Various ways to do is to cooperate with the government, private and public. It is expected of all households have access to the infrastructure for housing by the end of 2030 .

\section{CONCLUSIONS AND SUGGESTIONS}

Access to settlement infrastructure for housing included in the medium category. Only 5.26 percent of the districts are categorized as high. The region has a high accessibility and became the center of the population. Not all households can access residential infrastructure. Still found the household is not permanent, do not have latrines, and the use of drinking water is sourced from springs are not protected and unprotected wells. The household locations spread across all regions.

Suggestion, are cooperation is required between components inside of communities to achieve sustainable development goals by 2030 , so that all households can access residential infrastructure.

\section{REFERENCES}

[1] Adedayo, A, and A.O. Sulyman., 2015, "Assessment of Rural Dwllers Satisfaction with Quality of Infrastructure in Rural Settlements of Niger State, Nigeria", Journal Research on Humanities and Social Sciences, vol. 5 (13), pp. 78.

[2] Asnudin, A, 2009, "Infrastructure Rural Development with Local Community Involvement", Jurnal Smartek, vol. 7 (4), pp. 292-300.

[3] Baiquni, M. and Susilowardani, 2003, "Development is not Sustainable. Critical Reflection to the development of Indonesia", Second Edition, Ideas, Yogyakarta.

[4] Central Bureau of Statistics, 2003, "The National Economic Social Survey", Central Bureau of Statistics, Jakarta.

[5] Central Bureau of Statistics, 2011, "Indonesia Census 2010”, Central Bureau of Statistics, Jakarta.

[6] Central Bureau of Statistics, 2015, "Semarang District in Figures", Central Bureau of Statistics, Semarang.

[7] Dikun, S, 2003, "Indonesian Infrastructure: Before, During, and After the Crisis", the state Ministries PPN/BAPPENAS. 
[8] Ellis, F, 2000, "The Determinant of Rural Livelihood Diversification in Developing Countries", Journal of Agricultural Economics, vol. 51 (2).

[9] Fauzi. A, and Alex O., 2014, "The Measurement of Sustainable Development in Indonesia", Journal of Economic Development, vol. 15 (1), pp. 68-83.

[10] Hardati, P. 2014, "Spatial Patterns of Lingkages Between Farm and NonFarm Sectors and its Consequences on the Household Livelihood Strategies in Semarang Regency", Dissertation, Graduate Programme in Geography, Gadjah Mada University, Jogyakarta.

[11] Hardati, P, 2008, "Study Pattern Drinking Water Distribution Outlet Refill Based Geographic Information System in Semarang Regency", Semarang, Semarang State University.

[12] Hardati, P, and Rijanta, R, 2013, "Levels of Sustainable Livelihood and Distribution Spatial in Tengaran Sub District Semarang Regency, Central Java", Proceeding, International Seminar, Revitalization of Sustainable Development in New Era: Perspectives of Social Sciences, Semarang, State University of Semarang: 235-242.

[13] Hoelman, M.B, 2015, "Free SDGs For Local Government (City and Regency) and Regional Stakeholders", International NGO Forum on Indonesian Development.

[14] Kondoatie, R, 2005, "Introduction to Management Infrastructure”, Pustaka Pelajar, Yogyakarta.

[15] Rijanta, R, 2008, "Livelihood Strategies, Responses to the Crisis, and the Role of Non-Agriculture Activities in Five Villages in the Special Region of Yogyakarta. In Rural Livelihood, Resources and Coping with Crisis in Indonesia", ICAS Population Series, Edited by Milan J. Titus \& Paul P.M. Burgers, Amsterdam: Amsterdam University Press, vol. (3), pp. 153-176.

[16] Sam K.K, 2015, "Outcome Document Transforming Our World: The 2030 Agenda for Sustainable Development, Infid, Tifa, Ford foundation, ICCO, Australian AID", Mampu. New York, PBB. 